\title{
STRATEGIC INTIMACY, “REAL LOVE,” AND MARRIAGE
}

I was visiting with several women from Moldova who were living in Fatih, a neighborhood bordering Laleli, when the fourth woman staying in the one-bedroom apartment returned from her work as a cutter in a garment factory. Raia, a pleasant looking, blonde-haired woman with a strong and compact build, wanted to smoke, and she invited me to join her on a park bench outside the apartment building. Unlike most of her friends, Raia could sit in parks without fear of being spotted by police and threatened with deportation. Raia had a valid visa since her Turkish boyfriend, Ahmet, sponsored the cost of her travel home every month; each time she returned on a one-month tourist visa issued at the airport.

I first met Raia in 2006 when she had been traveling to Turkey for two years, and her son was three years old. After leaving an abusive husband in 2004, Raia departed for Turkey in search of a means to support herself, her son, and her aging parents. It was not hard to find work, and her cousin, who was already in Istanbul, acted as a reference. Raia had been working in a small wholesale clothing store selling women's suits for about a year when she met Ahmet. As a friend of the owner's he dropped by frequently, and it became apparent that he was drawn to her.

When they finally went out together, Raia said she cried; she felt conflicted and did not really want to date Ahmet. He asked her, "Don't you feel it in your heart, that we are meant to be close?" She told him no, she did not feel anything in her heart, but perhaps that would change. When she traveled home and consulted with her mother, Raia began to reconsider. Even though Ahmet was married and 
had two children in their twenties, Raia's mother-who used to work in the Soviet state farm system until it collapsed in the early 1990s and then briefly worked in Istanbul cleaning houses-encouraged her to take Ahmet's interest seriously. She said, "Well, maybe it is your fate; why don't you try it out and see how it goes?"

Raia recounted how Ahmet was really good to her, and she said, "He is like my brother, father, and boyfriend, all in one; this is much more than I could ever have imagined, and it is what I needed living in this foreign country, all alone with no family or anything." Like Raia, many women I met reflected on their attachment to boyfriends and on their boyfriends' support, which supplemented remittances home. Many others also recounted how they had contracted marriages of convenience or, as post-Soviet women migrants call these arrangements, "fake" marriage (fiktivnyi brak) to secure their status.

In this chapter I draw on multiple conversations, as well as formal interviews, with post-Soviet women primarily working long-term as sales assistants, exotic dancers, and domestic workers. I consider the central role that intimate ties with Turkish men play for migrants' efforts to maintain transnational circuits of intimacy between Turkey, Moldova and sometimes Russia. ${ }^{1}$ I came to know a wide range of women (and sometimes members of their families) from Moldova, Russia, Belarus, and Ukraine who had worked for one to fifteen years in different neighborhoods of Istanbul, including Aksaray, Laleli, Zetinburnu, Şişli, and Taksim. ${ }^{2}$ Although the women were employed in diverse spheres and were not always from the same post-Soviet countries, they had much in common, including their knowledge of Russian, the intimate ties they fostered transnationally, and frequently, the liaisons they negotiated with Turkish men.

In examining post-Soviet women's negotiations around various forms of intimacy they engage in as labor migrants in Istanbul, I explore the implicit line between "real" and "fake" or performed intimacy (see Brennan 2004). Women's deployments of intimacy could be seen as simply strategic, but women's narratives and diverse experiences provide evidence that complicates a simple binary of "true" intimacy and instrumental forms of intimacy. I also seek to show how the structural constraints under which women migrate from places like Moldova, Ukraine, and Belarus to Turkey shape decisions they make about intimate practices, including when and with whom to forge liaisons and whether to marry. Ultimately, I argue that the women I came to know are weighing emotional, material, and practical concerns around intimacy and negotiating their options within the confines of shifting Turkish border regimes and ideals about gender.

\section{Marriage, Love, Migration}

Popular estimates of the number of marriages between post-Soviet women and Turks tend to be vague, with numbers ranging from fifty thousand marriages 
contracted in one year to three hundred thousand "Turkish-Russian" marriages overall, but with no reference to the specific countries of origin for the women marrying Turkish men. ${ }^{3}$ For a number of reasons it is difficult to know what it means for women from the former Soviet Union to be married to Turks. Among the many issues, women could be married and then emigrate from Turkey, be married and then soon after divorced, or get married to a Turk working outside Turkey (e.g., in Russia). Nevertheless, data pertaining to marriage between foreigners and Turks, including that regarding post-Soviet women and Turks, suggest that from the mid-1990s to early 2000s marriage was an important avenue for securing citizenship (İçduygu 2009, 289).

While I met dozens of post-Soviet women migrants who had married in Turkey, and I heard about a number who had met and married their Turkish husbands for "true love" and settled in Turkey, only a few women I met claimed to have married in Turkey for "true love" (nastoiashchaia liubov'). Significantly, as of 2016 there were two avenues to gain citizenship in Turkey: (1) demonstrate Turkish "descent or culture" to be naturalized; or (2) marry a citizen. ${ }^{4}$ At least until the early 2000s, post-Soviet women appear to have widely turned to marriage as one way of securing their status to remain in Turkey long-term. Of the more than seven thousand women from the former Soviet Union who gained Turkish citizenship between 1995 and 2000, almost all of them did this through marriage to a Turkish citizen (İçduygu 2009, 289). ${ }^{5}$ After 2004, when borders and marriages became more thoroughly policed, women looked to this strategy for mobility less often.

Nevertheless, for many post-Soviet migrant women their lives were significantly shaped by intimate ties with Turkish men. As a number of scholars have noted for other locations (Constable 2003; Brennan 2004; Cheng 2007; CarrierMoisan 2012), marginalized women's negotiations around romantic liaisons and relationships defined by intimacy challenge assumptions of how "love" as an emotion might be experienced—namely, not always as separate from strategic concerns as some might imagine. Building on these insights in analyzing postSoviet migrant women's intimate practices, I seek also to show how the diverse types of liaisons women invested in during their long-term stays in Istanbul are part of transnational circuits of intimacy linking women's lives in Istanbul with their home communities.

\section{Intimacy and Mobility}

As cross-border marriages, virtual communities, and intimate service economies have become commonplace globally, new ways of forging intimacy have become widely imaginable; at the same time, mobile women like Raia are 
reconfiguring meanings they attach to relationships of love, obligation, and transaction, often finding these to be blurred (Constable 2003, 2005; Cheng 2007; Faier 2009). Like other scholars thinking about "intimacy" and its reworkings in a newly global era (Rebhun 1999; Hirsch and Wardlow 2006; Bernstein 2007a; Freeman 2007; Padilla et al. 2007; Constable 2009), I draw on this concept as a way of bridging the domestic, personal realm and related inward-looking tendencies with a more public and often politicized realm recognized as being shaped by global forces. "Intimacy" and "the intimate" may at first seem to fall into the realm of psychology and/or emotional terrain, a designation that would invoke universals, unmarred by larger social forces. However, as a number of scholars have shown, intimacy is also a space of negotiation where individuals face structural and geopolitical constraints tempered by a sense of possibility (Hirsch 2003; Constable 2003; Faier 2009), something that can be heightened by mobility. In thinking about forms of intimacy forged by people on the move, a dialectic of aspirations for personal transformation, on the one hand, and stark realities of structural constraints imposed by border regimes, on the other, create a productive space for reflecting on the ways that intimacy is shaped as much through emotion and the imagination as by material concerns and state power. Even as I show how impediments posed by border regimes shape the forms that intimacy takes, I also point to the complexity of motivations, structures of feeling, and emotional attachments that define women's migration experience.

\section{Intimate Economies in Shops and Homes}

The portrait of Raia's life traces details that parallel many of the relationships women forged with Turkish men. Moreover, Raia's experience also parallels a global trend of millions of people who have become labor migrants as local economies have faltered and demands for low-wage employment have expanded in more prosperous countries. Although transnational transfers of remittances are not unique to women migrants from the FSU, the ways in which post-Soviet women have widely engaged in intimate practices in Turkey are distinctive. Most ethnographic research among migrants in Turkey from the former Soviet Union and other former socialist countries has not focused on intimacy (e.g., Akalin 2007; Parla 2009; Keough 2015), and the scholarship that has considered intimacy emphasizes economic transactions (Yükseker 2004). Here I argue that negotiations around intimacy are not just about transactions, integral to the maintenance of the transnational circuits women maintain between Turkey and former Soviet countries, but are also about emotional ties and intersecting desires between Turkish men and post-Soviet women. 
Although some of the women I came to know in Istanbul were working as exotic dancers, and others more directly in sex work, many were employed in less stigmatized forms of labor as domestic workers, sales assistants, and, less commonly, in the garment industry. Almost all the women were widowed, divorced, or separated from husbands and fathers of their children, although some younger women had never been married or had children. Critically, post-Soviet migrant women's sensibilities about intimacy frequently fit with Turkish men's emerging desires to situate themselves as modern and cosmopolitan. This situation is reminiscent of what Leiba Faier writes about Filipinas traveling to Japan to work in politically and economically marginalized towns, where they were in demand as entertainers and often wives; as she suggests, in these spaces of working-class Japanese men's interactions with Filipinas, men could feel worldly, important, and superior when they "helped" Filipinas (2009, 37, 75).

Like Japanese men, Turkish men also voiced a desire to "help" migrant women they dated (and less often married). However, in contrast to what Faier outlines, with local Japanese hierarchies positioning Filipinas as culturally inferior to Japanese, Turkish men's desires for liaisons with post-Soviet women have pivoted around an opposite sense, that post-Soviet women are especially "cultured" and embody qualities men have sought to emulate and gain prestige from; by helping post-Soviet women, Turkish men could vicariously gain a sense of being modern and in some way upstanding as they maintained liaisons with the women. Just as intimate economies are defined and sustained within specific imaginaries and structures of power elsewhere in the world (Wilson 2004; Cheng 2007), in Istanbul waning socialist ideals, cultural imaginaries of secularism and Islam in Turkey, and new configurations of class mobility have come together to shape intimate economies.

These intimate economies were formed in two primary spaces, that of trade and the domestic realm. Postsocialist shuttle traders initially came to Laleli and encountered shopkeepers, sometimes Kurds who had relocated their trade as a result of Turkish state counterterrorism in eastern Turkey and later, in 1995, the first Iraq War (Shankland 2003; Yükseker 2004). ${ }^{6}$ As members of a marginalized and politicized minority group, Kurdish men I met described being drawn to post-Soviet women for their beauty and education but also for their origins in the FSU, a place where a sizable Kurdish diaspora resides, and a place historically sympathetic to Kurdish diasporas. ${ }^{7}$ One of my interlocutors even pointed to what she saw as a common political sensibility between herself and her Kurdish boyfriend, explaining, "He is a former socialist."

Within spaces of domestic employment middle- and upper-class Turks, most likely not identifying as Kurdish, also encounter post-Soviet women migrants. Turks have come to desire "Moldovans" as, irrespective of ethnicity, they tend to 
refer to Russian-speaking women who are employed in domestic labor (Keough 2015). As Leyla Keough explains, Moldovans working as domestics in Istanbul, many of whom identify as Gagauz, are valued for being "European, professional, educated, modern, clean, cultured and hard workers ... visible markers of a modern home" $(2015,123)$. Keough shows how women employed in domestic work evoke in Turks "cultural ideas based on their views of modernity" $(2015,99)$, views which simultaneously frame Moldovans as "white" and "Westernized" and, therefore, very likely "over sexed." This tension between being considered ideal workers and being feared, and sometimes desired, for embodying expressions of sexuality associated with Westernized, modern ideals encapsulates how Russianspeaking migrant women were widely perceived in Turkey during my research. While stereotypes would position these women as if their gender ideals and sentiments about sexuality were static, in fact, they have been forged over time.

\section{Sex/Gender Systems: Masculinity, Femininity, Sexuality}

The post-Soviet setting from which many women are migrating has seen radical shifts in what Gayle Rubin termed the "sex/gender system" (1975), or the way in which biological selves fit with social systems and gender expectations. As in other East European countries defined by state socialism, in the Soviet Union women were defined in a professional sense as working for the state and building state socialism, while still shouldering the primary responsibility of caring for families (Ashwin 2000; Gal and Kligman 2000). In part due to the disjuncture between ideology and reality, official policies of gender equality were one of the first tenets of an earlier era to come under attack in the popular culture of the late 1980s and early 1990s (Posadskaia 1994; Kay 2006; Hemment 2007). Likewise, by the late 1980s the decades of socialist discourse that sought to contain public discussion of eroticism and of the aesthetics of everyday life was also widely being critiqued. It became commonplace to encounter "erotica" (especially featuring women) in the media and public space and for men and women to freely reflect on sexuality (Attwood 1990; Kon 1995; Goscilo and Lanoux 2006); one of the most referenced examples of this new ethic was the blockbuster film Interdevushka, that portrays the life of a nurse turned foreigncurrency sex worker (Kunin 1991). ${ }^{8}$ By the late 1990s counterdiscourses across the region emerged, emphasizing that women should aspire to their "natural" roles and domestic spaces (Pine 2002b; Thelen 2003). This went along with a sharp binary gender model in which women were to be protected, appreciated, and supported by men and no longer defined by their roles in socially productive work (Temkina and Rotkirch 1997). 
Likewise, the prevailing sex/gender system within urban Turkey has undergone dramatic change since the 1980s. A range of feminist scholars have reflected on the ways patriarchy has shaped the society (e.g., Kandiyoti 1988b; Ozyegin 2015), including how queer and trans communities have experienced a dominant sex/gender system (e.g., Zengin 2013, 2016). Gul Ozyegin's work is especially useful in thinking about the relationships of urban Turkish men to post-Soviet women. Based on research among upwardly mobile young adults who were born in the 1980s, Ozyegin writes of how in the first part of the 2000s youth struggled to "renounce the [dominant] model of selfless femininity and protective masculinity," while remaining connected to the "social relations, identities, and histories"-what she calls "connectedness" - that defined their lives $(2015,3)$. Ozyegin notes major trends shaping how gender and sexuality were experienced in Turkey in the early 2000s, namely by: the diminishing power of a paternalistic state governing economic and civic life; the growing Islamization of the public sphere; and Turkey's bid to become part of the European Union $(2015,4)$. Within the context of these three broad trends, Ozyegin examines how upwardly mobile young men were renegotiating the relationship between selfhood and masculinity.

Ozyegin outlines forms of masculinity her consultants inherited from their fathers, which she calls "protective masculinity," and considers how the majority

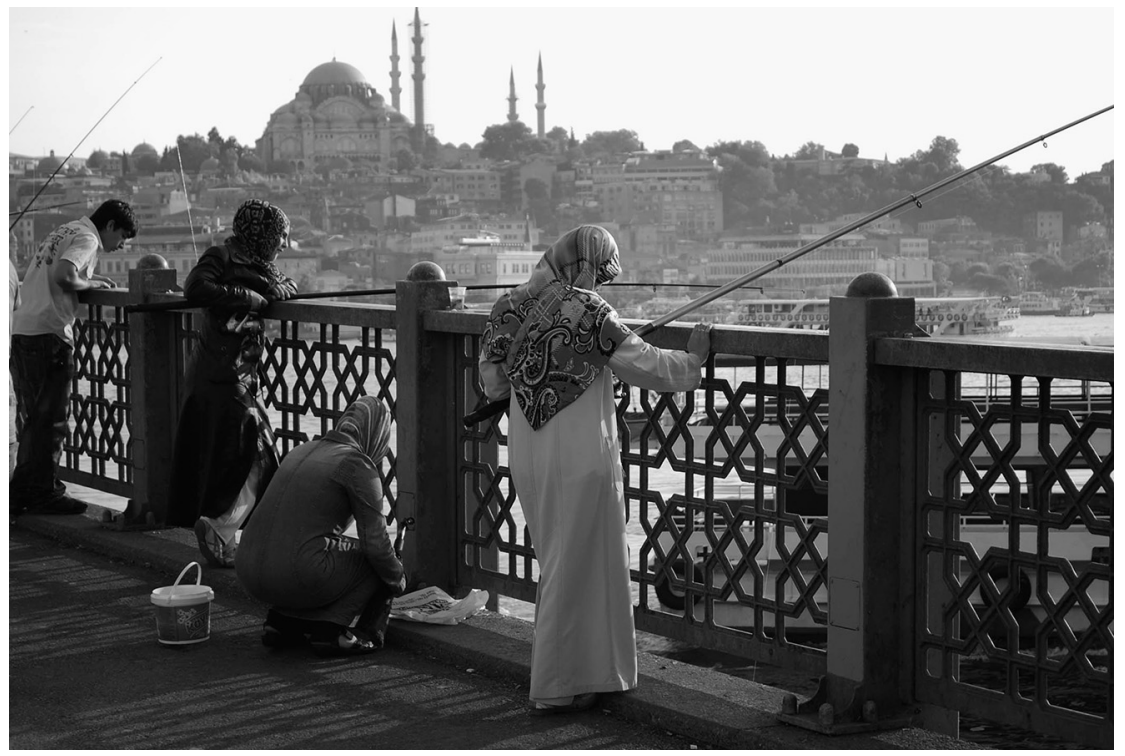

FIGURE 17. Women fishing off the Galata Bridge. Photograph by Jared Bloch, 2009. 
of men she interviewed resisted this form of masculinity, instead looking to other ways of shaping a masculine self. Nevertheless, she argues that "facades" make it possible for upwardly mobile young men to appear to refute "patriarchal constructions of masculinity as controlling and dominant while [in fact, still] exercising gender domination" $(2015,5)$. Based on interviews with twenty-two men, Ozyegin traces the feminine ideals that upwardly mobile men held, which revolved around a dichotomy. On the one hand, men identified potential girlfriends as "ambitious," "charismatic," and what they called, "selfless" women who were willing to support men's egos and the development of their selfhood and ambitions. On the other hand, they also identified potential girlfriends as being "selfish" women who were independent and focused on realizing their own ambitions $(2015,109)$. Ozyegin convincingly shows how heterosexual young men in her study were drawn to both types of women. "Selfish" women who are perceived as modern, affirm men's need for recognition, attesting that the men are progressive and able to refute ideas of "protective," dominating masculinity, while "selfless" or positive women encourage men, support them, and reinscribe ties to social norms, including around gender and dominant masculinity $(2015,120)$. Ozyegin found that while men overwhelmingly voiced a desire for partners who were independent and pursued their own needs, men were mostly in relationships with women who affirmed their egos, acting with "maternal selflessness."

As Turkish men are negotiating what forms of masculinity to embrace in their lives, post-Soviet women have been widely faced with what some scholars have called "a crisis of masculinity" in their home communities. This is thought to be one of the key reasons that Russian-speaking women engage in transnational marriage migration (Luehrmann 2004; Patico 2010). Jennifer Patico examines how a crisis of masculinity compels Russian-speaking women to seek out marriage especially with North American and West European men in an effort to become "more positively valued and evaluated" $(2010,19) .{ }^{9}$ Patico notes that women turned to international marriage services to look for husbands because they had struggled in home communities of Belarus and Russia to find husbands who would be financially stable, sober, and not abusive, but also to find husbands who would provide for them both materially and emotionally $(2010,25)$. Some women also recounted that they found the more gender-egalitarian attitudes in the domestic realm, especially among American and Canadian men, to be appealing. Patico points to the need to consider the intertwining of economic and emotional concerns that contribute to the appeal of foreign spouses for Russian-speaking women $(2010,32)$. Significantly, Patico goes on to examine how a certain "crisis of masculinity" in the United States is another crucial part of the story explaining why American men and Russian-speaking women find each other appealing; the American men perceive an erasure of gender differences as 
central to contemporary calls for gender equality in North America, and they see American women as too often lacking femininity and "family orientation" but also too materially concerned and self-centered $(2010,38)$. Russian-speaking women, who often find normative family arrangements unattainable in the conditions of economic strain in the former Soviet Union, look to marriages with Western men to fulfill aspirations for attaining their ideal families. As Patico concludes, both Western men and post-Soviet women are looking to be "differently valued, differently desirable, and differently competitive" (2010, 40).

The intersecting sex/gender systems Patico examines as key in drawing Russian-speaking women and North American men to one another, significantly resonate with the relationships I observed between Russian-speaking migrant women and Turkish men. These relationships seem to enact a "protective masculinity" enabled by a certain interlocking of Turkish men's desires for women they can care for, with post-Soviet women's search for men who can provide materially and emotionally for them. The particular configurations of Turkish masculinity, shaped by what Ozyegin sketches as ideal female partners being either "selfless" or "selfish," also seem to temper how Turkish men widely encounter Russian-speaking women migrants. Post-Soviet women labor migrants embody an ideal combination of characteristics; they seem to appeal to some Turkish men in combining features of "selfless" and "selfish" women. Post-Soviet women migrants are desired for being educated, savvy in wielding their sexuality, and independent but could also be seen to simultaneously massage male egos and fulfill what Ozyegin describes as men's need to affirm dominance through performing roles as providers.

Many post-Soviet women migrants I came to know in Istanbul drew on their intimate relationships with Turkish men to help them sustain their social ties with their children, grandchildren, and parents (and more rarely spouses) across time and space, as well as sometimes to sustain themselves emotionally. And while some women relied on men to smooth their residency status by arranging marriages of convenience, a practice that could provide financial security, women's relationships with Turkish men were also part of their place-making efforts in Istanbul. Thus distinct intimate practices permeated the transnational circuits maintained by post-Soviet women labor migrants.

\section{Secularism, Islamists, and Signs of Modernity}

In the "market war over identities" that emerged as the moderate Islamist Justice and Development Party (AKP) came to power in 2002, secularist and Islamistidentified Turks reaffirmed their deeply held beliefs; in some ways commodities signified modernity for both groups. For years the portrait of Mustafa Kemal 
Atatürk, the founder of the Turkish Republic, acted as a "secularist" commodity, where not only in government spaces but also in households and commercial sites images of the former leader were prominently displayed..$^{10}$ These images were meant to showcase allegiance to ideals of "militant" secularism that were enshrined in public discourse and institutions by the founder of the Turkish Republic; the images also heralded Turkey's transformation into a modern, secular society, proclaiming itself as no longer impeded by religion (Reynolds 2011, 260). ${ }^{11}$ In a similar manner, the türban, or newly fashioned bright headscarf worn by an increasing number of Turkish women since the 1990s, has signaled a religious modernity for many Islamists, where women's modesty is key (Navaro-Yashin 2002, 229-38). These signifiers of very different modernities have remained salient as the tension between secular and Islamist allied segments of society has intensified along with the steadily increasing support for the Justice and Development Party.

The AKP's support since the early 2000s springs, in part, from being the first Islamist party in the history of the Turkish state to become a ruling party and to address recurrent concerns of marginalization raised by religious proponents and more economically marginalized segments of the population. However, the AKP has also gained popularity because of Prime Minister Erdoğan's ability to rally populist sentiment that castigates "secularists," as well as a wide array of others who do not support the AKP (e.g., Kurds, atheists, Alevis, feminists, leftists, etc.) (Hansen 2017). ${ }^{12}$ The AKP positions itself as religiously moderate but nevertheless in opposition to the paradigm of Kemalist secularism that has defined the country since the establishment of the Republic in 1923. The AKP has embraced ideals of a free market economy and, intermittently, accession to the $\mathrm{EU}$, along with firm renegotiation of the relationship of the secular state to religious practice, including in regard to gender ideals. For instance, in 2011 the AKP prevailed in passing legislation making it legal for women to wear headscarves in most state institutions, such as universities, except not as employees in government offices; in 2013 this "democratization package" legislation was extended to encompass nearly all state institutions, and in 2016 it was extended to the police force (Taşpınar 2012; Turkey Allows 2016).

Expressions of support for Islamist ideals in the form of gendered codes of modesty contrast starkly with the increasingly visible markers of liberal ideals around sexuality and desire that widely defined secular urbanite Turkish women's sensibilities in the early 2000s (Öncü 1999; Potuoğlu-Cook 2006), as well as Russian-speaking migrant women's sensibilities. ${ }^{13}$ The context of Turkey, specifically Istanbul, is a reminder that the politics of place critically shape how people envision possible gender roles and ideals, and how they understand sexuality and desire (White 1999; Öncü 2002, 171). With the influx of migrants in the 
late 1990s, Turkish men and Russian-speaking women began to forge distinctive structures of intimacy revolving around perceptions of each other's sexuality. Women in the shuttle trade and those living and working for years in Istanbul encountered the logics of intimacy defining them as potentially sexually available. Deniz Yükseker (2004) argues that post-Soviet wholesale buyers made the most of these logics and drew on forms of "strategic intimacy," including a wide array of flirtatious interactions, to secure favorable prices on the merchandise they exported home.

During my research marginalized, low-wage labor migrants also engaged in forms of strategic intimacy, albeit with more long-term aims that went well beyond securing favorable pricing for merchandise. Unlike for the traders, the ability of women labor migrants to work beyond the term of their one- or twomonth tourist visa was tied to their ability to negotiate intimacy. While skills in negotiating sexual innuendo grease the business exchanges Yükseker (2004) describes and are generally a form of reciprocal exchange, the forms of intimacy that my interviewees sought out were fundamental to their long-term wellbeing and often blurred the divide between emotional and instrumental ties or between love and transaction. These intimacies could lead to secure housing, permanent residency, and substantial benefits for dependents, including those back home or those now making a living in Russia, but they could also lead to lasting relationships. These forms of intimacy emerged in a context of marginalization, where a large group of women turned to strategic intimacy to garner some security for their dispersed families. These strategies became especially important as Turkey began more systematic policing of migrant women from the former Soviet Union.

\section{Of Marriage and Mobility}

In 2004, after more than a decade of relatively open borders for citizens arriving from the former Soviet Union, the Turkish state began to tighten border controls. This followed on the heels of 2003 legislation that imposed restrictive measures on marriages between Turks and foreigners. With the passage of the law foreigners marrying Turkish citizens now had to endure a three-year waiting period before they were allowed to apply for citizenship, a process that included a rigorous in-person interview and, frequently, a visit to applicants' residences. The introduction of this legislation was widely viewed as "protecting" innocent Turkish men from Russian women who sought marriages of convenience (Hacaoğlu 2002). The wording of the law does not identify specific ethnic groups, but it appears to have emerged in response to public opinion vilifying women labor migrants from the former Soviet Union as "Natashas," or possible "prostitutes," 
often suspected of being "disease spreaders" who were scheming to gain Turkish citizenship (Béller-Hann 1995, 231-32; Hacaoğlu 2002). ${ }^{14}$

Just as prior to 2003 it was common for women migrants who were deported from Turkey to remarry in their home communities and thereby receive new passports issued with new surnames, it was also common for women migrants from the former Soviet Union to arrange a marriage of convenience to a Turkish citizen. As Polina, a woman working as a shop assistant told me: "In those days it was really simple and it cost nothing; I paid about $\$ 5$ to a coworker in the late 1990s, and we got married. I did not see him again for twenty years, and I was able to get my residency and citizenship really quickly. These days it has become impossible!"15 Nadia, who had worked as an entertainer told me, "I was lucky because I did my fake marriage at the right time and got my citizenship easily; that's why I could get my [property management] business established and even build a house for my mother back home." Unlike Polina, Nadia, and other women who arrived in the 1990s and early 2000s, those who arrived later could not rely on simply conducting an inexpensive business transaction to secure their legal status in Turkey. They had even more reasons to seek out long-term intimate relationships with Turkish men.

The marriages I heard about that women had contracted more recently often involved considerable sums and a boyfriend paying a third party for the arrangement. If in the past women could easily afford to pay for these arrangements themselves, with the increased policing of marriages between Turks and foreign women the costs rose. Because my consultants were usually romantically involved with married Turkish men, the arrangements for marriages of convenience typically involved financial compensation to a third party, often a student. The marriages I heard about in the mid-2000s involved women's lovers making payments of as much as $\$ 500$ per year to "husbands" until women obtained their citizenship. Women relied on assistance from their romantic partners to facilitate their legal status; they first became temporary residents and, after three years and the requisite interview, if all went well they could become citizens (and get divorced).

\section{Marriage and Intimate Liaisons through Time}

Over the past 150 years, marriage as an institution has undergone significant transformations in Europe and North America and has shifted from an institution based on financial or familial obligation to one based on "companionate marriage" or marriage based on love (Hirsch and Wardlow 2006). ${ }^{16}$ In late nineteenth-century Constantinople the same ideals became popular among elite segments of the population, and by the 1920s they circulated more widely (Başc1 2003). ${ }^{17}$ Although marriages meant primarily to secure ties between families were commonplace in this period, discourses of "love" and "choice" had taken 
hold in relation to marriage (Duben and Behar 1991, 96-97). A dual standard, however, remained in which "decent women" could not have love affairs, while it was widely understood that men could have liaisons with concubines (cariyes) or prostitutes and have co-wives (Vergin 1985, 573; Duben and Behar 1991, 96; Başc1 2003). Concubines were often Circassians (from southern Russia) who worked as indentured servants in Constantinople homes, and some Ottoman men considered them desirable marriage partners and mistresses (Duben and Behar 1991, 145). ${ }^{18}$ In the late nineteenth and early twentieth centuries, possibly in imitation of the Ottoman sovereign's prerogatives, high-ranking government officials sometimes had multiple wives. Even after Turkey instituted the 1925 marriage code, which legally enforced monogamous marriage, well into the 1960s, at least in Istanbul, it was not unheard of for more established men to have more than one wife (Duben and Behar 1991, 156). ${ }^{19}$ Halide Edib, considered part of the Turkish literary canon, commented at the turn of the nineteenth and twentieth centuries that such arrangements reflected how "'modern' men of wealth, power, and status were not quite modern" (Başc1 2003, 156-57). It appears that with the heightened mobility of post-Soviet women, the practice of multiple marriages, or at least the desire to "keep" a woman, again raises questions about how ideals of modernity and intimacy relate to one another.

Post-Soviet women's mobility and the associated liaisons women form with Turkish men highlight how closely linked transnational border crossing is with shifting structures of intimacy in Turkey and, as a few scholars have argued, with shifting structures of intimacy in the former Soviet Union (Bloch 2003b; Luehrmann 2004; Patico 2010). According to Béller-Hann (1995), the arrival of Russian-speaking migrant women in northeastern Turkey in the 1990s evoked public concern about the degree of financial and emotional investment men made in these women and prompted the circulation of discourses on how postSoviet women were destroying Turkish families. In the name of families, local feminist organizations called on government authorities to make it more difficult for post-Soviet women to cross into Turkey; according to these narratives Turkish men were drawn helplessly into the alluring arms of migrant women. From another perspective, however, these cross border liaisons echo what Nicole Constable has written about transnational intimacies as building on men's and women's "contradictory transnational fantasies, desires, and imaginings of marriage, tradition, and modernity" $(2005,3)$.

\section{“Kept" Woman, Mistress, and Wife}

While post-Soviet women migrants I met widely sought liaisons with Turkish men, these arrangements ranged from being "kept" women to wives to mistresses. The ways in which women positioned their relationships were closely 
linked to options back home, their visa status-that is, whether they were on temporary work visas, had overstayed a one- or two-month tourist visa, or had ever been deported - and their keen perception of themselves as sexualized bodies within Turkey. As Anna, a twenty-three-year-old exotic dancer from Ukraine who worked in Turkey on multiple contracts in nightclubs explained: "I agreed to being a 'kept' woman for my boyfriend once, but only for two months, not a day longer. I was bored stiff! He paid for my apartment, bought me clothes, everything, including $\$ 100 /$ week spending money, but he expected me to be home all the time except when I went out for aerobics. It was unbearable!" This perspective on being "kept" was less typical for older women.

Being a "kept" woman was a status sought out by many women I met in their thirties and forties, who were often employed as sales assistants or domestic workers. For instance, Alexandra, a forty-two-year-old woman from Moldova who was employed as a domestic worker, told me that she wished her boyfriend (drug) would be willing to "keep" her. He did rent a modest apartment where they met once a week on her days off, but Alexandra lamented that her boyfriend was "afraid" of his wife so would not agree to fully support her. Other women, like Inna, a thirty-one-year-old woman from Belarus, described how she enjoyed being "kept" as a better alternative to unemployment at home or the low-paid, unglamorous employment as a domestic worker that could require travel to distant suburbs like Beykoz, or the exhausting job of a sales assistant in Aksaray or Laleli. Inna described how she was happy when she met her boyfriend Hassan and he courted her with presents of jewelry and nights on the town. When he offered to rent an apartment and provide spending money to cover her needs, Inna quit her job and took up the offer.

\section{Negotiating Terms of Intimacy}

In contrast to the Filipinas and Chinese Constable $(2005,169)$ writes about, or the marriages Patico (2010) discusses, where women sought to marry North American men in part as a means to "more egalitarian" relationships, the postSoviet women I came to know generally saw their lives with Turkish men differently. They rarely spoke of their relationships in terms of equality but instead in terms of economic and legal stability, and sometimes romance. As Alexandra explained to me, "You can get by on just a job, but life is much easier with a man around; just about everyone I know has a Turkish boyfriend." Inna said, "All women like these nice things, a little perfume, a new dress, and some romance; we have a hard time getting these things at home where our men are often drinking, earn little money, and have forgotten about how to please women." Often a 
relationship with a Turkish man permitted women to send home larger remittances; bring mothers, children, or grandchildren for summer vacations to Turkey; and expand employment opportunities. Overall, women emphasized the idea of legal stability and financial support created through these ties, but emotional considerations factored in as well.

Although women spoke of the financial concerns that had driven them to seek work in Istanbul, discursively they often deemphasized a simple material exchange with men. They invoked the idea that men "help" (pomogaiut) them and their families and thereby pointed to the complexity of their relationships with Turkish men. One might argue that this could be a linguistic ploy by the women to make their situations feel more acceptable, but it was also common for Turkish men to be entangled in women's family obligations. For instance, in the role of "boyfriend," several men took part in attending and financing wedding celebrations for women's family members back home or working in Russia, while others, like Niki's boyfriend Ali, sponsored summer visits to Istanbul for women's mothers or children or traveled to Moldova and Russia for New Years' celebrations with women's families. In this way, many women described their boyfriends as fulfilling provider roles but also filling emotional, companionate, and sometimes physical needs. As one woman told me, "No one can live for years on end without human warmth; of course many of us seek out Turkish boyfriends."

Women's accounts often featured their mothers encouraging them to consider the benefits of living as Turkish men's mistresses. Raia, the woman whose portrait opened this chapter, explained that her mother back in Moldova advised her to pursue a relationship, saying, "Your heart might not feel anything now, but that can come with time." Raia reasoned that her decision must have been right; her boyfriend turned out to really care about her young son back home in Moldova and often gave her money to help Raia's mother care for him. Women and their families, or at least their mothers, were carefully weighing how ties to Turkish men could help ease the desperate material circumstances back home.

The forms of intimacy migrant women forge in their adopted countries, where they often work for years on end, are both strategic and potentially fostered by mutually appealing concerns where "love," "romance," and material benefit merge. Like other scholars blurring this line between "real" marriage practices and marriages of convenience and questioning the divide between "love" and instrumentality (Freeman 2007; Faier 2009), in the following portraits of postSoviet women maintaining transnational circuits between Turkey and their homelands I consider how mobility, love, and intimacy intersect. 


\section{NIKI}

When I was departing from Moldova in 2005, Nelli urged me to be in touch with her daughter, Niki, in Istanbul. When I phoned her, Niki invited me to visit her and explained how to take the suburban train from Aksaray out to her area. I exited the station and was met by an elegant young woman dressed in a crisp powder-blue linen suit. We went to sit in a park near Niki's apartment where young children played soccer and elderly couples were vigorously walking.

Niki recounted how she had come up against the Turkish state's restrictions on undocumented migrants. She arrived in Istanbul in 1996, when the economic devastation following the end of the Soviet Union made it impossible for her to make a living as a hairdresser. This, in addition to a failed marriage, gave her few means to support her five-year-old daughter. Leaving her daughter with her mother, Nelli, Niki drew on a contact in Vulcăneşti to find a job in a drugstore in Istanbul. After working there for less than a year, one of the male employees began sexually harassing her, and Niki left. Niki eventually secured work in a clothing store as a sales assistant, where she worked for over a decade but with significant effort on her part.

As Niki explained, in addition to employing her in 1997, the owner of the store, Ali, soon hired her brother. After nearly three years of working as a sales assistant, primarily serving as an interpreter for the Russian-speaking wholesalers shopping at the store, one day the police apprehended Niki and her brother and took them into custody. In court Niki and her brother pleaded that they were not working for the store but simply engaged in wholesale transactions of clothing to resell back in Moldova. The judge pressed them to explain why they were at the store on overstayed tourist visas. They said it was expensive for them to go back and forth, and they had combined a holiday with their business trip. In short, they testified that it was a mistake, but that they were not working for the store. ${ }^{20}$ Partly because of Niki and her brother's loyalty and willingness to protect him, Ali was able to influence an official and avoid a hefty fine for hiring undocumented workers. ${ }^{21}$ Niki and her brother were ultimately deported, and Ali paid for their way home to Moldova.

They had been home less than a month when Ali called to invite them back. Niki's brother did not want to return-he preferred instead to travel to Moscow for work-but Niki returned to Turkey, using a new passport issued in her maiden name. Niki resumed her old job and moved into an apartment that Ali had rented for her. Several years later, Ali arranged a marriage of convenience for Niki with a student he knew, and Ali and Niki waited for Niki's permanent residency to be processed..$^{22}$ In subsequent years Niki returned to Moldova almost yearly, and Ali accompanied her; he even attended Niki's brother's wedding. By 2009 Niki decided to quit her job at the store and remain at home in the 
apartment, explaining that while she could not be married to her "lover," she had converted to Islam as a sign of her devotion to him. (Notably, that same year, with Niki's residency application denied, it became dangerous for her to be visibly present at her former workplace.) The way that Niki spoke of her relationship over the years shifted between the terms "boss" (khoziain, in Russian or patron, in Turkish), "boyfriend" (in English), and "lover" (liubovnik, in Russian), suggesting the fluid nature of the relationship. Where initially Ali was simply an employer, over time he became a lover.

As with Niki's relationship, the long-term relationships many women have with Turkish men often involve reciprocal forms of care, emotional support, and leisure time spent together; not infrequently, women convert to Islam as a sign of their sincerity, and men take part in key ritual events in women's home communities. However, since the women rely so much on patronage in the form of financial support and sponsorship for fictive marriage arrangements, some troubling power imbalances also define these relationships. As in the narrative that follows, women rely on different logics at different points during their stay in Istanbul and women sometimes weigh the costs of contracting marriages, especially a "love" marriage.

\section{MARIA: GAMBLING WITH “REAL” MARRIAGE}

When Zina first introduced me to her friend in 2003, Maria was dressed in a leopard-skin patterned synthetic shirt, tightly fitting tan pants, and low pumps; this chic and rather sexily clad woman turned out to be a grandmother, sales assistant, and former radio technician, among other things. By 2009 Maria had worked in Istanbul for over fifteen years. She established herself as a sales assistant, helping wealthy Russian-speaking clients, like Ania, the successful shuttle trader, select clothing for resale in high-end boutiques back home. In 2003 Maria earned about $\$ 400$ a month in salary, and by 2009 she earned about $\$ 800$ per month. ${ }^{23}$ In addition to this, each month she could count on several hundred dollars in tips and gifts from clients who appreciated her skill in selecting models of clothing that were in demand back in Russia. Maria considered herself lucky, but she struggled to cover expenses, including \$150/month for rent, and regular remittances for her two young adult sons in Moldova, as well as for her daughter and two grandchildren living in Moscow.

In 2005 Maria decided to marry a man who was sixty-five, fifteen years her senior; soon after the marriage Maria moved in with her new husband, a retired shoemaker with a small pension that barely covered their rent. Maria explained to me, she had "fallen in love"; the marriage was not fake, but "real" (nastoiashchii), although Maria also later told me she left a younger lover for her future husband who was more likely to provide her with long-term material security. Several of 
Maria's friends were skeptical of her motivations for marrying. Her close friend Zina, whose sister Eva had hosted me in Moldova, and who had worked as a domestic in Istanbul for fifteen years, reflected, "Everyone is anxious about securing housing and avoiding deportation, but Maria has sold herself!" (prodalas'). From Zina's perspective, Maria was forcing herself to ignore the boorish nature of her retired husband just to secure Turkish citizenship.

After several months Maria's friend Zina became even more outraged by the marriage, explaining: "He is home all day and does nothing! He has a miserly income. Maria is at work all day and comes home to a pile of dishes, to cooking, and cleaning.... Excuse me, but I would never agree to lie with that living corpse [zhivoi trup] in one bed! . . . how can Maria bear it, living with someone who does not respect her? He treats her like a servant!" Zina's critique hinged on her perception of the lack of real benefits to the marriage, either in material form or in the form of "true love" or even romance. However, Maria insisted she was "in love," and besides, she saved on rent, and this money could be sent to her daughter in Moscow and her sons in Moldova or saved for the house she was renovating back home in Moldova.

Zina simply refused to call this a "real marriage" (nastoiashchii brak). From her perspective, "a man should respect and pay attention to his wife; it is not simply that they are living together or sharing a bed, they should have basic human interactions, not like a living corpse, simply existing." She intoned that it was poor judgment for Maria to marry and wondered, "Why not simply work hard, and deal with the fines on exiting the country? What does she really get out of it?"24

As evident from this narrative, not all women agreed about the benefits of becoming involved with Turkish men. In castigating Maria for "selling herself" by contracting a "real marriage," Zina's commentary emphasizes the conundrum in which women find themselves. Older women especially have fewer men seeking to maintain them as "kept" women or mistresses, so contracting "fake" marriages paid for by boyfriends is difficult to arrange. Moreover, as reflected in Niki's narrative, since the mid-2000s marriages of convenience between Turks and post-Soviet women are stringently policed for what the state perceives as fraud. Securing residency status, and thereby the long-term possibility to work in Turkey, has become more difficult. In these circumstances, Zina judged Maria for getting married "for real" and dedicating her life to caring for someone just to secure her residency status.

Women frequently spoke of having more power from a position of an illicit relationship than they would in a "real marriage." The exchange they demanded for maintaining relationships was for Turkish men to contribute to their material well-being. Remittances, goods, and better earning power are all part of the 
intimate circuits women seek to foster through the relationships with Turkish men. "Real" marriage curtails this form of power since women are no longer bargaining with men; once married, women tend to find themselves constrained by the rules of relationships that position them as providing domestic laborcooking, cleaning, and washing - without remuneration and potentially without meaningful intimacy. As Alexandra quipped when I asked if she would ever consider marrying her Turkish boyfriend, "Well, like them all, he's already married. Besides, he makes a much better lover than a husband."

A focus on intimacy as central to transnational migration highlights how gender matters to the study of migration. First of all, sex/gender systems shape the intimate practices of migrants. In the case of post-Soviet women migrants, they depart from countries where public discourse is widely defined by post-Soviet gender ideals positioning women as in need of men's protection and sponsorship. Once in Turkey, post-Soviet women encounter the widespread public imagination of "Russian" women in the region as sexualized others who live physically distant from close family members for months on end. Women like Raia, Niki, and Maria find themselves turning to relationships with Turkish men both as a means of seeking out "human warmth" while they live long-term in Istanbul, as one consultant explained, and as the only tangible means of potentially securing residency in Turkey. Thus in this case gender matters, as women are keenly aware of how their prospects for safeguarding long-term transnational mobility are very much defined by intimate relationships with Turkish men.

Migrants enmeshed in shifting structures of feeling and constrained by immigration and citizenship regimes in receiving countries draw on intimate relationships to enable their roles as providers for households back home, but also sometimes to fulfill their own needs for meaningful relationships. By considering intimate practices of migration both in material terms and in terms of reciprocal emotional exchange, perhaps we come closer to portraying migrants' experiences. Post-Soviet migrant women engage in intimacy with Turkish men in a context defined by the Turkish state but also by shifting gender ideals in Turkish society. In a way, migrant women are engaged in a set of nested intimacies where many women draw on relationships to better funnel remittances to loved ones in home communities, but like Niki they also sometimes fall in love in Turkey. Not unlike other cases of "love," here the line between "love," or emotional ties, and material security is one that blurs and shifts over time, but especially when women spend years on end without legal status in Turkey.

Public policy in Turkey continues to define migrant women's intimate practices. As of 2017 the Justice and Development Party was firmly entrenched as the ruling party in Turkey, and it has continued measures to circumscribe migrants' 
options by stepping up police raids on clubs, where some undocumented postSoviet women work, and increasing sweeps of public spaces where post-Soviet migrant workers from diverse backgrounds gather after work and on their days off. With few other means of regularizing their status, the state continues to indirectly push women to seek increased economic security in the form of intimate relationships. While undocumented post-Soviet migrants continue to work and live in Istanbul, as in other metropoles of the EU, Asia, and North America, their lack of avenues to a regularized, if not permanent, status significantly shapes the ways they forge intimacies in a precarious world. 